\title{
Effect of Corporate Income Tax Incentives on Investment in Rwanda
}

\author{
Jean Bosco Harelimana ${ }^{1, *}$ \\ ${ }^{1}$ Institut d'Enseignement Superieur de Ruhengeri, Musanze, Rwanda \\ *Correspondence: Institut d'Enseignement Superieur de Ruhengeri, P.O.B. 155 Musanze, Musanze, Rwanda. E-mail: \\ harelijordan@yahoo.fr
}

Received: September 5, 2018

Accepted: September 23, $2018 \quad$ Online Published: October 13, 2018

doi:10.5430/mos.v5n4p1

URL: https://doi.org/10.5430/mos.v5n4p1

\begin{abstract}
The purpose of this study was to establish the effect of corporate income tax incentives on investment using private sector manufacturing companies in Kigali special economic zone, Rwanda. The study adopted descriptive research design and the study population comprised of thirty-nine manufacturing companies in free zone in Rwanda which are registered by the private sector. The sample size comprised of 36 private companies determined from a total population of 39 companies. Only two employees that are acquainted with decision making from each manufacturing companies registered by the private sector were targeted hence the target population respondents was 72 respondents. The Stratified random sampling technique was used to select the respondents. Data was collected from both primary and secondary data using questionnaires and documentation. The findings in the study revealed that tax incentives have significant positive effect on investment in private sector manufacturing companies in Rwanda. The $\mathrm{p}$-values for all the variables are lower than 5\% this implies that are significant. From the study the p-values are $0.009,0.000$, 0.003 and 0.000 for company income tax, capital allowance, value added tax and capital gains tax incentives respectively. The capital allowance incentive has the highest $t$ value of 4.656 , followed by company income tax incentives with 3.954, and next is capital gains tax incentives with 3.184, while the lowest is the value added tax incentives with 2.954. Based on the empirical evidences and results of the analysis, there is positive and statistically significant relationship between the tax incentives and investments. The study recommends that Government and policy makers should concentrate on efforts at ensuring that more CIT incentives and strategies that are specifically addressing small and medium enterprises are introduced.
\end{abstract}

Keywords: corporate income tax, tax, tax incentives and investment

\section{Introduction}

There has been deferent approaches to tax incentive has over the years. Tax incentives are considered as a tool that is used to stimulate economic growth and development. According to Fletcher (2012), tax incentives are special exclusions, exemptions or deductions, from income tax liability, offered to taxpayers by the government as an enticement or encouragement to engage in specified activities. Tax incentives can also be defined as special arrangements in the tax laws to attract, retain or increase investment in a particular sector (Ifueko, 2009). This can help the government to stimulate growth in specific areas and assist companies or individuals carrying on identified activities. Tax incentives form the fundamental basis to ensure the overall growth of the economy and even development of all sectors Ifueko (2009). It is in this regard that tax incentives can be considered as tax deductions given to taxpayers to encourage or support specific course of action intended to encourage investment in certain sectors or geographical areas.

Oyetunde (2008) found out that, company income tax rates incentives were successfully used in Nigeria and stimulated economic growth. Hines \& Rice (2014) analysed the effect of taxes incentives on the foreign direct investment by comparing the inter-state distribution of investments with foreign investment in United State of America. The study used regression analysis. The results from the survey showed that high tax rates within the state hurt the local investment. The study conducted by Bond \& Xing (2013) on the effect corporate tax rate and depreciation allowances on the level of investment revealed a significant effect on investment in assets. However, contradicting results were identified in the study conducted by Wheeler \& Mody (2012), their study conclude that 
corporate taxes do not have a significant effect on FDI.

An interesting model of production to analyze the impact of tax policies on input demands and output supply for producers operating in selected industries in Mexico, Turkey and Pakistan was introduced by (Bernstein \& Anwar (2014). Their study analysed the following tax incentives Investment allowances, accelerated capital consumption allowances, corporate income tax rate reductions and investment tax credits. The Bernstein - shah model results suggest that tax incentives are necessary for investment and production decisions.

Clarete (2012) examined the effects of tax incentives on the imported machinery and equipment by priority industries. The study concluded that there is a strong impact tax incentive on investment. In the study carried out by Feldstein (2007) on the efficacy of tax incentives on investment, the result showed that investment allowance and investment tax credit are more simulative in its impact on private capital formulation. First investors emphasize more on incentives, such as subsidies, reduce cost of establishment, while firms that reinvest, prefer more incentives that deal with taxation, such as tax-holidays, accelerated depreciations and loss-carry forwards and loss-carry backwards (Stapper,2010). In other words, firms that have started their activities in a new country have different preferences about their motives in relevance with firms that expand their activities (Rolfe et al., 1993).

Depreciation and capital allowances are more preferable to tax holidays in Uganda. This is because it has been established that, they specifically encourage new investment (UNCTAD, 2000). Similar findings are also seen in the study carried out by Morisset \& Pirnia (2010) who out find that developed countries prefer investment allowances or accelerated depreciation. Under investment allowance, companies are allowed to depreciate their assets with a certain percentage. The Rwanda investment codes of 2015 provides that an investor is allowed to depreciate his her assets by $50 \%$ if is a registered investor and has invested in new or used assets with a value of 50,000 USD.

The Eclectic theory is demonstrated by Dunning $(1980,2000 \&$ 2008) illustrates three different theories of investments based on the following advantages (O-L-I). Ownership advantages (O), Location advantages (L) and Internalization advantages. This theory is termed as the OLI theory or framework. All the three factors are important in determining the pattern and extent of FDI.

Eclectic theory embraces all existing theories of investments. The theory is a framework for identifying some determinants of investments. Nevertheless, the eclectic theory provides a useful tool - kit for those who are interested in study of the foreign investment location decision. The OLI theory is relevant to consider the process of establishing why Rwanda has attracted investments because of tax incentives offered which is the highlight of this study. The existence of weaknesses in all of the investments theories has been identified in the literature that each of the theories could partly explain certain aspects relating to the motivation of investments of non- existence a single theory (Denisia, 2010). Countries should attract investments by reducing inherent costs and derive maximum benefit. Because of this, most countries grant tax incentives to attract investments.

The ownership advantage, and location advantages has been cornerstone for different countries in establishing transnational corporations. When the first two conditions are met, it becomes profitable for the company to use these advantages with some other factors outside the country of origin as stipulated by (Dunning, 2014). Tax can affect all the three OLI conditions. Firstly, it can affect the treatment of tax of the foreign firms for locational factors. All these factors that underly the OLI theory are very important to aid companies to compete easily in the host country and consider the process of determining whether or not Rwanda has attracted investments because of the tax incentives offered which is the intention of this study as highlighted.

According to African development bank and IMF (2006), show that tax incentives in East Africa do not attract foreign investment. The study further shows that most countries that have been successful in attracting foreign direct investment do not use tax incentives. Governments in East Africa provide a range of tax incentives to businesses to attract greater levels of FDI into the country. In total, Kenya, Uganda, Tanzania and Rwanda are losing up to US\$2.8 billion a year from tax incentives and exemptions. Not all of these mechanisms are bad. Some, such as VAT reductions, can help reduce poverty. But much of the revenue loss is explained by tax incentives provided unnecessarily to attract foreign investment. These revenue losses are depriving countries of critical resources needed for reducing poverty (Action aid, 2012).

A tax incentive is a way of minimizing taxes for business and individuals in exchange for specific Rwandan government has continued offering tax incentives to various sectors of the economy despite slow growth in GDP within the last four years. Lack of evaluation on the performance in relation to contribution to development has resulted to major loss of income which could have otherwise been used in social welfare of Rwandan citizens. This study focused on establishing whether reforming tax incentives structure in Rwanda would aid in exploiting the full 
potential of the key economic sectors with respect to investments.

Law number 6/2015 on investment codes provides various investment incentives to various companies in Rwanda. These include preferential corporate income tax of $0 \%$ and $15 \%$, corporate income tax holidays of seven and five years, accelerated depreciation on investment in assets, exemption on capital gain on movable assets, VAT refund in fifteen days, resident permit to foreigners. In addition, to the investment incentives available to companies, tax laws also provides incentives to companies such loss carried forward, discount on listing shares and depreciation (Government of Rwanda, 2018, 2015).

As discussed above many scholars have tried to show the effect of tax incentives on level of investment, however, none of the studies have investigated the effect of corporate tax incentive on the investment in Rwanda. This study therefore attempts to an answer to the following research question: What is the effect of tax incentive on investments of private sector manufacturing companies in Kigali special economic zone Rwanda.

The tax laws provide various tax incentives to the business enterprises. These includes corporate income tax holidays of seven and five year, loss carried forward for a period of five years, capital allowances which includes accelerated depreciation for investment in new or used assets of 50\%, reduction in CIT rate which includes the preferential CIT rate of $0 \%$ and $15 \%$ and also reduction in the CIT rate based on the percentage of shares listed at Rwanda stock exchange market and the tax free dividends from local companies. These incentives have got a direct effect on the level of investment which can be measured in increase in the assets, market growth and retained earnings. However for this relationship to exist, factors such as the size of the company, level of investment, government policy and ignorance of the tax laws should be put into considerations.

\section{Methodology}

\subsection{Research Design}

Orodho (2013) defines research design as the scheme outline or plan that is used to generate answers to research problems. Survey research design with specific reference to descriptive research design and correlation research design was utilized in this study. Kothari (2014) states that a descriptive research design is useful when the researcher objectives include determining the degree to which one variable (dependent) affect the other variable (independent). The tax incentives were regressed against the investments in private sector manufacturing companies in Kigali special economic zone Rwanda. Qualitative and quantitative approach was used. In quantitative approach the study employed data in form of numbers collected from employees on manufacturing companies. Qualitative was used through interviews in order to establish the effect of tax incentives on investment in private sector manufacturing companies in Kigali special economic zone Rwanda.

\subsection{Study Population}

The study population was 39 private companies which operate in special economic zone. However, the study targeted only two employees that are acquainted with decision making from each manufacturing companies registered by the private sector. These two employees included the managers and directors of finance in each manufacturing company. These categories were chosen because of their knowledge about finance and tax policies in Rwanda.

Table 1. List of Manufacturing Companies Targeted

\begin{tabular}{lcc} 
& Sectors & Numbers \\
\hline Consumer goods & 5 \\
Conglomerates & 2 \\
Services & 3 \\
Health care & 3 \\
Industrial goods & 23 \\
Stores & 3 \\
Total & 39 \\
\hline
\end{tabular}

Source: Primary data, 2018

\subsection{Sample Design \& Sample Technique}

A sample size of thirty-six (36) private manufacturing companies was determined from a total population of 
thirty-nine (39) private manufacturing companies using the formula by Yamane (1967). Two employees were purposively selected from the sampled companies the number of respondents was seventy-two (72). Stratified random sampling technique was used to select the respondents. Stratified random sampling technique ensures that different groups of a population are adequately represented in the sample. Stratified sampling divides the population into homogeneous groups such that the elements within each group are more alike than the elements in the population as a whole (Nachimas \& Nachimas 2008).

$$
n=\frac{N}{1+N(e)^{2}}
$$

Where $\mathrm{n}=$ the desired sample size

$\mathrm{e}=$ probability of error (i.e., the desired precision, e.g.,0.05for $95 \%$ confidence level)

$\mathrm{N}=$ the estimate of the population size.1.0975.

$$
n=\frac{39}{1+39(0.05)^{2}}=36
$$

Table 2. Sample Size

\begin{tabular}{lcc}
\hline \multicolumn{1}{c}{ Sectors } & Numbers & Sample \\
\hline Consumer goods & 5 & 5 \\
Conglomerates & 2 & 2 \\
Services & 3 & 3 \\
Health care & 3 & 3 \\
Industrial goods & 23 & 21 \\
Stores & 3 & 2 \\
Total & 39 & 36 \\
\hline
\end{tabular}

Source: Primary data, 2018

\subsection{Data Collection Procedures}

Data was collected using questionnaires and interview. Open and closed ended questionnaires were sued. The study also used 'Likert Scale' (considered on 1-5 points scale) to measure the respondents' perceptions based on few statements to establish the effect of tax incentives on investment in Rwandan manufacturing companies. The points of the scale indicate the degree of agreement ' 1 ' represents the lowest level of agreement or high disagreement, whereas ' 5 ' represents the highest level of satisfaction or high agreement.

\subsection{Data Processing and Analysis}

The collected data was examined and checked for completeness and comprehensibility. The data was then summarized, coded and tabulated. Descriptive statistics such as frequency distribution was used to analyze the data. Data presentation was done by the use of frequency tables for ease of understanding and interpretations. Before processing the responses, the completed questionnaires were edited and classified for completeness and consistency. Data was then coded and tabulated to enable the responses to be grouped into various categories using Statistical Package for Social Science (SPSS version 21). Data was analyzed using content analysis and specifically the conventional content analysis approach. This approach was the best for this research since the questionnaire was self-administered

A multiple regression model was used in this study:

$$
\begin{gathered}
\mathrm{Y}=\alpha+\beta_{1} \mathrm{X}_{1}+\beta_{2} \mathrm{X}_{2}+\beta_{3} \mathrm{X}_{3}+\beta 4 \mathrm{X}_{4}+\beta 5 \mathrm{X}^{+}+\mu \\
\mathrm{Y}=\text { Dependent variable }- \text { Investment } \\
\alpha=\text { Constant } \\
\mu=\text { Error } \\
\beta=\text { Coefficients } \\
\mathrm{X}_{1}=\text { CIT holiday }
\end{gathered}
$$


$\mathrm{X}_{2}=$ Capital allowances tax incentives

$\mathrm{X}_{3}=$ loss carried forward

$\mathrm{X} 4=$ reduction in CIT rate

$\mathrm{X} 5=$ Tax free dividends

Factor analysis of the individual tax incentives (company income tax incentives, such as CIT holiday, capital allowances, loss carried forward, reduction in CIT and tax free on dividend incentives on investments. Simple analysis of variance (ANOVA) was used to look for significant differences between the individual tax incentives. SPSS (Statistical Package for Social Sciences) software program was used for in-depth data analyses. Analyzed data was then presented using tables, pie charts, percentages, and text.

\section{Results}

This section shows how the data collected from the survey was presented and analysed. The tables were presented using frequency and percentage, with the key: $\mathrm{SD}=$ Strongly Disagree; $\mathrm{D}=$ Disagree; N=Neutral; A=Agree; SA $=$ Strongly Agree to express frequency of each fact. The mean (M) and the standard deviation (SD) of each hypothesis are also computed.

\subsection{Effect of Corporate Income Tax (CIT) Incentives on Investment}

The effect of company income tax incentives on investment using private sector manufacturing companies in Kigali special economic zone Rwanda was examined with the following five statements in Table 4.1. The respondents were asked to indicate their level of agreement with given statements concerning whether company income tax incentives are effective in attracting investments in private sector manufacturing companies in Kigali special economic zone Rwanda. Respondents' opinion on company income tax incentives on investment using private sector manufacturing companies in Kigali special economic zone Rwanda was examined was captured using 5-Strongly disagree; 4 Disagree; 3 - Indifferent; 2 - Agree; 1 -Strongly agree. The statements, respondents' opinions and their percentages are as shown below:

Table 3. Company Income Tax Incentives

\begin{tabular}{lccccccc}
\hline Statements & $\begin{array}{c}\text { SD } \\
\mathbf{\%}\end{array}$ & $\begin{array}{c}\mathbf{D} \\
\mathbf{\%}\end{array}$ & $\begin{array}{c}\mathbf{N} \\
\mathbf{\%}\end{array}$ & $\begin{array}{c}\text { A } \\
\mathbf{\%}\end{array}$ & $\begin{array}{c}\text { SA } \\
\mathbf{\%}\end{array}$ & $\begin{array}{c}\text { Mean } \\
\text { Company income tax is effective in attracting investments in }\end{array}$ & $\begin{array}{c}\text { Std. } \\
\text { Dev }\end{array}$ \\
manufacturing companies Rwanda. & 2 & 4 & 9 & 17 & 32 & & \\
Tax free dividends encourage free flow of investments to the & $(3.1)$ & $(6.3)$ & $(14.1)$ & $(26.6)$ & $(50.0)$ & 4 & 1 \\
manufacturing companies & $(1.6)$ & $(7.8)$ & 5 & 17 & 36 & & \\
Exemption from minimum tax increases investments inflows & 0 & 8 & 17 & 20 & 19 & & \\
& $(0.0)$ & $(12.5)$ & $(26.6)$ & $(31.2)$ & $(29.7)$ & 4 & 1 \\
Loss carried forward relief is an important incentive & 0 & 3 & 15 & 26 & 20 & & \\
attracting investments in manufacturing companies & $(0.0)$ & $(4.7)$ & $(23.4)$ & $(40.6)$ & $(31.2)$ & 4 & 1 \\
Tax holidays encourage inflow of investments & 0 & 4 & 5 & 32 & 23 & & \\
& $(0.0)$ & $(6.3)$ & $(7.8)$ & $(50.0)$ & $(35.9)$ & 4 & 1 \\
\hline
\end{tabular}

Source: Primary data, 2018.

Table 4.1 shows that $26.6 \%$ of the respondents agreed, $14.1 \%$ were neutral, $50.0 \%$ strongly agreed, while $6.3 \%$ disagreed and $3.1 \%$ strongly disagreed. The results show that majority of the respondents believed company income tax is effective in attracting investments, since over $76 \%$ agreed with the statement. The mean is 4 (agree) implying that majority agreed with the statement with a small variation of 1 (standard deviation is 1 ). The findings are in line with Chaves (2010) who found out that company income tax leads to increase in investment.

The study intended to establish if tax - free dividends encourage free flow of investment using private sector manufacturing companies in Kigali special economic zone Rwanda. The result shows that $26.6 \%$ agreed, $7.8 \%$ were neutral while $1.6 \%$ disagreed. The majority $(56.3 \%)$ were of the opinion that tax free dividends encourage free flow of investments into the manufacturing companies. The mean is 4(agree) implying that majority agreed with the statement with a small variation of 1 (standard deviation is 1 ).

On whether exemption from minimum tax increases investments inflows, $31.2 \%$ of respondents agreed, $29.7 \%$ 
strongly agreed, $26.6 \%$ were neutral while none strongly disagreed and $12.5 \%$ disagreed. This implied that majority agreed that exemption from minimum tax increases investments. The mean is 4 (agree) implying majority agreed that exemption from minimum tax increases investments, with a small variation of 1 (standard deviation is 1 ).

The results on if loss carried forward relief is an important incentive in attracting investments in manufacturing companies indicate that, $40.6 \%$ of the respondents agreed, $31.2 \%$ strongly agreed, $23.4 \%$ were neutral, $4.7 \%$ disagreed and none strongly disagreed. The results show a loss carried forward relief is an important incentive in attracting investments in manufacturing companies since over $71 \%$ were in agreement with the statement. The mean is 4(agree) implying that majority agreed with the statement with a small variation of 1 (standard deviation is 1 ).

The study found out if tax holidays encourage inflow of investments. The results indicate that $50.0 \%$ agreed, $35.9 \%$ strongly agreed, $7.8 \%$ neutral, $63 \%$ disagree. This implies that majority of the respondents agreed that tax holidays encourage inflow of investments. The mean is 4 (agree) implying that majority agreed with the statement with a small variation of 1 (standard deviation is 1 ).

The study further requested respondents to indicate whether they were enjoying tax incentives.

Table 4. Companies Enjoying Tax Holidays

\begin{tabular}{llcc}
\hline & Frequency & Percent \\
\hline Valid & Yes & 24 & 37.5 \\
& No & 40 & 62.5 \\
& Total & $\mathbf{6 4}$ & $\mathbf{1 0 0 . 0}$ \\
\hline
\end{tabular}

Source: Primary data, 2018

As stated in Table 4.2 the findings revealed that majority $62.5 \%$ of the companies do not enjoy tax holidays while $37.5 \%$ enjoy. This finding is in line with study conducted by Sebastian, (2009) that the tax holiday is the principal form of corporate tax incentive currently applied in Egypt". The author emphasized that many developing countries offer tax holidays as one of their main incentives to attract new investment. Tax holidays were very popular with the countries reviewed, with over $75 \%$ of the sample offering some form of tax holiday, generally between 5-15years.

\subsection{Effect of Capital Allowances Incentives on Investment}

The study sought the view of the respondents in regard to the effect of capital allowances incentives on Investment in private sector manufacturing companies in Kigali special economic zone Rwanda. Respondents' opinion on capital allowances on tax incentives on investment using private sector manufacturing companies in Kigali special economic zone Rwanda was captured using 5-Strongly disagree; 4 - Disagree; 3 - Indifferent; 2 - Agree; 1 -Strongly agree. The statements, respondents' opinions and their percentages are as shown below:

Table 5. Capital Allowance Incentives

\begin{tabular}{|c|c|c|c|c|c|c|c|}
\hline Statements & $\begin{array}{l}\text { SD } \\
\%\end{array}$ & $\begin{array}{l}\mathrm{D} \\
\%\end{array}$ & $\begin{array}{l}\mathbf{N} \\
\%\end{array}$ & $\begin{array}{l}\mathbf{A} \\
\%\end{array}$ & $\begin{array}{l}\text { SA } \\
\%\end{array}$ & Mean & $\begin{array}{l}\text { Std. } \\
\text { Dev }\end{array}$ \\
\hline $\begin{array}{l}\text { Initial and annual allowances are importan } \\
\text { incentives in attracting investment }\end{array}$ & $\begin{array}{c}2 \\
(3.1)\end{array}$ & $\begin{array}{c}4 \\
(6.3)\end{array}$ & $\begin{array}{c}9 \\
(14.1)\end{array}$ & $\begin{array}{c}17 \\
(26.6)\end{array}$ & $\begin{array}{c}32 \\
(50.0)\end{array}$ & 4 & 1 \\
\hline $\begin{array}{l}\text { Investment allowance is a method used to encourage } \\
\text { investment in Rwanda manufacturing Companies }\end{array}$ & $\begin{array}{c}1 \\
(1.6)\end{array}$ & $\begin{array}{c}5 \\
(7.8)\end{array}$ & $\begin{array}{c}5 \\
(7.8)\end{array}$ & $\begin{array}{c}17 \\
(26.6)\end{array}$ & $\begin{array}{c}36 \\
(56.3)\end{array}$ & 4 & 1 \\
\hline $\begin{array}{l}\text { Rural investment allowance encourages in flow of } \\
\text { investment in Rwanda manufacturing Companies }\end{array}$ & $\begin{array}{c}0 \\
(0.0)\end{array}$ & $\begin{array}{c}8 \\
(12.5)\end{array}$ & $\begin{array}{c}17 \\
(26.6)\end{array}$ & $\begin{array}{c}20 \\
(31.2)\end{array}$ & $\begin{array}{c}19 \\
(29.7)\end{array}$ & 4 & 1 \\
\hline $\begin{array}{l}\text { Foreign entities are satisfied with the present level of } \\
\text { investment allowance to attract investment }\end{array}$ & $\begin{array}{c}0 \\
(0.0)\end{array}$ & $\begin{array}{c}3 \\
(4.7)\end{array}$ & $\begin{array}{c}15 \\
(23.4)\end{array}$ & $\begin{array}{c}26 \\
(40.6)\end{array}$ & $\begin{array}{c}20 \\
(31.2)\end{array}$ & 4 & 1 \\
\hline $\begin{array}{l}\text { Investment allowance supports expansion in existing } \\
\text { Rwandan manufacturing companies }\end{array}$ & $\begin{array}{c}0 \\
(0.0)\end{array}$ & $\begin{array}{c}4 \\
(6.3)\end{array}$ & $\begin{array}{c}5 \\
(7.8)\end{array}$ & $\begin{array}{c}32 \\
(50.0)\end{array}$ & $\begin{array}{c}23 \\
(35.9)\end{array}$ & 4 & 1 \\
\hline $\begin{array}{l}\text { Capital allowance incentives are effective incentives } \\
\text { used to attract investment in Rwanda manufacturing } \\
\text { Companies }\end{array}$ & $\begin{array}{c}0 \\
(0.0)\end{array}$ & $\begin{array}{c}4 \\
(6.3)\end{array}$ & $\begin{array}{c}5 \\
(7.8)\end{array}$ & $\begin{array}{c}32 \\
(50.0)\end{array}$ & $\begin{array}{c}23 \\
(35.9)\end{array}$ & 4 & 1 \\
\hline
\end{tabular}

Source: Primary data, 2018 
Table 4.3 established the effect of capital allowances incentives on investments using private sector manufacturing companies in Kigali special economic zone Rwanda. On the importance of initial and annual allowances in attracting investments, the study findings revealed that $26.6 \%$ of the respondents agreed, $14.1 \%$ were neutral, $50.0 \%$ strongly agreed, $6.3 \%$ disagreed while $3.1 \%$ strongly disagreed. The majority of $76 \%$ confirmed that initial and annual allowances are important in attracting investments. The mean is 4(agree) implying that majority agreed with the statement with a small variation of 1 (standard deviation is 1 .

The study found out if investment allowance is a method used to encourage investment in the manufacturing sector. $26.6 \%$ of the respondents agreed, $7.8 \%$ were neutral, $56.3 \%$ strongly agreed, $7.8 \%$ strongly disagreed while $1.6 \%$ disagreed. The mean is 4 (agree) implying that majority agreed with the statement with a small variation of 1 (standard deviation is 1). This implies that majority of the respondents agreed that investment allowance is a method used to encourage investment in the manufacturing sector.

On the question of whether rural investment allowance encourages in flow of investments in private sector manufacturing companies in Kigali special economic zone Rwanda, the results revealed that $31.2 \%$ agreed, $26.6 \%$ neutral and $12.5 \%$ disagreed. The mean is 4 (agree) implying that majority agreed with the statement with a small variation of 1 (standard deviation is 1 . In response to the view that foreign entities are satisfied with the present level of investment allowance to attract foreign direct investment was agreed by $40.6 \%$ of the respondents, strongly agreed by $31.2 \%, 23.4 \%$ were neutral, $4.7 \%$ disagreed while none strongly disagreed. The mean is 4 (agree) implying that majority agreed with the statement with a small variation of 1 (standard deviation is 1).

On the facts that investment allowance supports expansion in existing listed manufacturing companies, $50.0 \%$ agreed, while $7.8 \%$ were neutral, $35.9 \%$ strongly agreed, $6.3 \%$ disagreed and none strongly disagreed. These results show that majority of the respondents agreed with the view that investment allowance supports expansion in existing listed manufacturing companies. The mean is 4 (agree) implying that majority agreed with the statement with a small variation of 1 (standard deviation is 1). Investment allowance is aimed at encouraging re-investment of profits.

The study investigated if capital allowances are effective incentives used to attract investments in private sector manufacturing companies in Kigali special economic zone Rwanda. $50.0 \%$ of the respondents agreed, $7.8 \%$ were neutral, $35.9 \%$ strongly agreed, $6.3 \%$ strongly disagreed while none disagreed. Majority agreed with the statement that capital allowances are effective incentives used to attract investments in private sector manufacturing companies in Kigali special economic zone Rwanda. The mean is 4(agree) implying that majority agreed with the statement with a small variation of 1 (standard deviation is 1).

\subsection{Claiming of Total Capital Allowance to Reduce Its Taxable Profit}

The study further requested respondents to indicate whether claiming of total capital allowance reduced its taxable profit.

Table 6. Claiming of Total Capital Allowance to Reduce Its Taxable Profit by Companies

\begin{tabular}{llcc}
\hline & Frequency & Percent \\
\hline Valid & Yes & 36 & 56.3 \\
& No & 28 & 43.7 \\
& Total & $\mathbf{6 4}$ & $\mathbf{1 0 0 . 0}$ \\
\hline
\end{tabular}

Source: Primary data, 2018

As presented in Table 4.4, 56.3\% of the respondents suggested that their companies claim total capital allowance to reduce its taxable profit. While $43.7 \%$ responded that, their companies did not claim total capital allowance to reduce profit.

\subsection{Descriptive Analysis on Investments (Dependent Variable)}

The study sought the view of the respondents in regard to the investment in private sector manufacturing companies in Kigali special economic zone Rwanda. Respondents' opinion on opinion on investment using private sector manufacturing companies in Kigali special economic zone Rwanda was captured using 5-Strongly disagree; 4 Disagree; 3 - Indifferent; 2 - Agree; 1 -Strongly agree. The statements, respondents' opinions and their percentages are as shown below: 
Table 7. Respondents Views on Investments

\begin{tabular}{|c|c|c|c|c|c|c|c|}
\hline Statements & $\begin{array}{l}\text { SD } \\
\%\end{array}$ & $\begin{array}{l}\mathrm{D} \\
\%\end{array}$ & $\begin{array}{l}\mathbf{N} \\
\%\end{array}$ & $\begin{array}{l}\mathbf{A} \\
\%\end{array}$ & $\begin{array}{l}\text { SA } \\
\%\end{array}$ & Mean & $\begin{array}{l}\text { Std. } \\
\text { Dev }\end{array}$ \\
\hline $\begin{array}{l}\text { The investment climate for investors is very } \\
\text { conducive in attracting equity participation in } \\
\text { Rwanda manufacturing Companies. }\end{array}$ & $\begin{array}{c}1 \\
(1.6)\end{array}$ & $\begin{array}{c}2 \\
(3.1)\end{array}$ & $\begin{array}{c}5 \\
(7.8)\end{array}$ & $\begin{array}{c}26 \\
(40.6)\end{array}$ & $\begin{array}{c}32 \\
(50.0)\end{array}$ & 4 & 1 \\
\hline $\begin{array}{l}\text { Companies do reinvest their earnings in } \\
\text { manufacturing sector }\end{array}$ & $\begin{array}{c}0 \\
(0.0)\end{array}$ & $\begin{array}{c}0 \\
(0.0)\end{array}$ & $\begin{array}{c}4 \\
(6.3)\end{array}$ & $\begin{array}{c}20 \\
(31.2)\end{array}$ & $\begin{array}{c}40 \\
(62.5)\end{array}$ & 4 & 1 \\
\hline $\begin{array}{l}\text { Foreign participation in Rwanda manufacturing } \\
\text { companies increases the flow of foreign assets. }\end{array}$ & $\begin{array}{c}0 \\
(0.0)\end{array}$ & $\begin{array}{c}8 \\
(12.5)\end{array}$ & $\begin{array}{c}17 \\
(26.6)\end{array}$ & $\begin{array}{c}20 \\
(31.2)\end{array}$ & $\begin{array}{c}19 \\
(29.7)\end{array}$ & 4 & 1 \\
\hline $\begin{array}{l}\text { There is high prospect in the attraction of } \\
\text { investment in Rwanda manufacturing Companies. }\end{array}$ & $\begin{array}{c}0 \\
(0.0)\end{array}$ & $\begin{array}{c}3 \\
(4.7)\end{array}$ & $\begin{array}{c}15 \\
(23.4)\end{array}$ & $\begin{array}{c}26 \\
(40.6)\end{array}$ & $\begin{array}{c}20 \\
(31.2)\end{array}$ & 4 & 1 \\
\hline $\begin{array}{l}\text { Most investments inflows into Rwanda are in } \\
\text { form of equity participation. }\end{array}$ & $\begin{array}{c}1 \\
(1.6)\end{array}$ & $\begin{array}{c}5 \\
(7.8)\end{array}$ & $\begin{array}{c}5 \\
(7.8)\end{array}$ & $\begin{array}{c}17 \\
(26.6)\end{array}$ & $\begin{array}{c}36 \\
(56.3)\end{array}$ & 4 & 1 \\
\hline
\end{tabular}

Source: Primary data, 2018

In this study, investment was the dependent variable statements as shown in Table 4.5. Majority of the respondents $(50.0 \%)$ agreed that the investment climate for foreign investors is very conducive in attracting equity participation in manufacturing companies. The mean is 4(agree) implying that majority agreed with the statement with a small variation of 1 (standard deviation is 1). In response to the opinion that companies do reinvest their earnings in manufacturing sector, $62.5 \%$ strongly agreed, $31.2 \%$ agreed, $6.3 \%$ were neutral, while none neither disagreed and nor strongly agreed. These results indicate that $90 \%$ of the respondents agreed with the opinion that companies do reinvest their earnings in manufacturing sector. The mean is 4(agree) implying that majority agreed with the statement with a small variation of 1 (standard deviation is 1). $31.2 \%$ agreed that foreign participation in listed manufacturing companies increase the flow of foreign assets, $29.7 \%$ strongly agreed, $26.6 \%$ were neutral and $12.5 \%$ disagreed. These findings imply foreign participation increase the flow of foreign assets. The mean is 4(agree) implying that majority agreed with the statement with a small variation of 1 (standard deviation is 1).

The study determined if there is high prospect in the attraction of foreign direct investment on investment in private sector manufacturing companies in Kigali special economic zone Rwanda. 40.6\%, agreed with the statement, $31.2 \%$ strongly agreed, $27.3 \%$ were neutral and $5.2 \%$ disagreed. Finally, on the opinion that most investments inflows into Rwanda are in form of equity participation, $26.6 \%$ agreed with the statement, $56.3 \%$ agreed $7.8 \%$ were neutral while $7.8 \%$ disagreed. These results indicate that majority of the respondents agreed that most investments inflows into Rwanda are in form of equity participation. The mean is 4 (agree) implying that majority agreed with the statement with a small variation of 1 (standard deviation is 1).

Table 8. Most Effective Tax Incentives in Attracting Investments

\begin{tabular}{llcc}
\hline & Frequency & Percent \\
\hline Valid & Initial and annual allowance & 12 & 18.8 \\
& Loss carry forward relief & 11 & 17.2 \\
& Tax holiday & 10 & 15.6 \\
& Reduction in CIT rate & 9 & 14.1 \\
Tax free dividends & 14 & 21.9 \\
Capital gains tax relief & 8 & 12.5 \\
Total & $\mathbf{6 4}$ & $\mathbf{1 0 0 . 0}$
\end{tabular}

Source: Primary data, 2018

According to Table 4.5, the most effective tax incentive in attracting investments is company income tax with a percentage response of $21.9 \%$, while the least effective tax incentives Capital gains tax relief with a percentage response $12.5 \%$. 


\subsection{Multiple Linear Regressions for Tax Incentives and Investments}

The general objective of the study was to establish the effect of tax incentives on investment using private sector manufacturing companies in Kigali special economic zone Rwanda. The effect of the tax incentives on investments and the statistical significance of the variables were established with multiple linear regression analysis. Results of the regression analysis are presented below.

\subsection{Model Summary}

Regression analysis was done to determine the relationship between tax incentives and investments.

\section{Table 9: Model summary}

\begin{tabular}{ccccc}
\hline Model & $\mathrm{R}$ & R Square & Adjusted R Square & Std. Error of the Estimate \\
\hline 1 & $.934^{\mathrm{a}}$ & .889 & .881 & .727 \\
\hline \multicolumn{5}{c}{$\begin{array}{l}\text { Predictors: (Constant), CIT holiday, Capital Allowance } \\
\text { reduction in CIT rate. Tax free dividends }\end{array}$} \\
\hline
\end{tabular}

\section{Source: Primary data, 2018}

According to Table 18, $\mathrm{R}=0.934$, this indicates that there is a strong relationship between the tax incentives and investments. While $\mathrm{R}$ - square $=0.889$, this indicates that $88.9 \%$ variation in investments is explained by all the combined income tax tax incentives (independent variables) while the remaining $11.1 \%$ is explained by other factors.

3.7 ANOVA

To determine the level of significant ANOVA test was done on tax incentives on investments.

Table 10. ANOVA Results Showing the Combined Effect ANOVA ${ }^{b}$

\begin{tabular}{llccccc}
\hline Model & & Sum of Squares & Df & Mean Square & F & Sig. \\
\hline \multirow{2}{*}{1} & Regression & 22.191 & 4 & 5.548 & 19.999 & $.000^{\mathrm{a}}$ \\
& Residual & 9.709 & 35 & .277 & & \\
& Total & 31.900 & 39 & & & \\
\hline
\end{tabular}

b. Dependent Variable: Investments

c. Predictors: (Constant), Company Income Tax Incentives, Capital Allowance Incentives, Value Added Tax Incentives and Capital Gains Tax Incentives

Source: Primary data, 2018

The ANOVA test in Table 20 indicates that the significance of the $\mathrm{P}$ value 0.000 is less than 0.05 , implying that null hypothesis is rejected, and alternative hypothesis accepted. It is concluded that there is a significant effect of all the four incentives on investments.

\subsection{Overall Regression Model Coefficients}

Overall coefficients were done on the four variables of tax incentives on investments.

Table 11. Coefficient Results

\begin{tabular}{llccccc}
\hline Model & & \multicolumn{2}{c}{$\begin{array}{c}\text { Unstandardized } \\
\text { Coefficients }\end{array}$} & $\begin{array}{c}\text { Standardized } \\
\text { Coefficients }\end{array}$ & t & Sig. \\
\hline & B & Std. Error & Beta & & \\
\hline & 0.174 & .060 & & & .006 \\
(Constant) & 0.162 & .046 & .444 & 3.954 & .009 \\
Company income tax holiday & .050 & 2.231 & 4.656 & .000 \\
Capital allowance tax incentives & 0.285 & .050 & 1.075 & 2.956 & .003 \\
Loss carried forward & 0.149 & .052 & 2.230 & 3.184 & .000 \\
Reduction in CIT rate & 0.219 & .044 & .889 & 3.758 & .000 \\
Tax free dividends & 0.124 & .033 & & & & \\
\hline
\end{tabular}

Source: Primary data, 2018 
From the data in the above table the established regression equation was

$\mathrm{Y}=0.174+0.162 \mathrm{X} 1+0.285 \mathrm{X} 2+0.149 \mathrm{X} 3+0.219 \mathrm{X} 4+0.124 \mathrm{X} 5$

From the above regression equation, it was revealed that holding CIT holidays, loss carried forward, capital allowances, reduction in CIT rate and tax free dividends to a constant zero, investments would be at 0.174.

The beta coefficients were subjected to further test and the resulting model in Table 4.7 shows that all the tax incentives have significant positive effect on investments. While the p-values for all the variables are lower than 0.05 . In the estimated model, capital allowance is highly significant at 5\% level in explaining investments. The results indicate that capital allowance has the highest beta coefficient of 0.285 . The beta value of 0.285 implies that a unit change in capital allowance incentives will lead to 0.285 units change in the volume of investments. However, value added tax has the lowest coefficient of 0.149 . The beta value of 0.149 implies that a unit change in value added tax incentives will lead to 0.149 units change in the volume of investments. The capital allowance incentive has the highest $t$ test of 4.656 and the lowest is company income tax.

From the study the p-values are $0.009,0.000,0.003,0.000$ and 0.000 for CIT holidays, loss carried forward, capital allowances, reduction in CIT rate and tax free dividends respectively. The capital allowance incentive has the highest $\mathrm{t}$ value of 4.656, followed by company income tax incentives with 3.954, and next is capital gains tax incentives with 3.184 , while the lowest is the value added tax incentives with 2.954 . They are all significant at less than $0.05 \%$. The capital allowance incentives have the highest effect on investments while the company income tax has the lowest effect on investments private sector manufacturing companies in Kigali special economic zone Rwanda.

\section{Discussions}

Moriseet \& Pirnia (2003) state that there is little importance of company income tax on investments. Even though there are studies suggesting that company income tax incentives are very important for investments. However, changes in taxation and investments in a particular country are mostly inconclusive. But most theoretical studies suggest that company income tax incentives are effective in attracting investments.

The study by UNCTAD, (2010 show that most Africa countries have put in place a collection of tax incentives to promote regional development such as income tax exemption or reduced tax rate. However, studies on whether generous tax policies can compensate for weaknesses in the commercial environment and attract FDI have led to the broad conclusion that tax exemptions can influence some of the investors (Morisset \& Pirnia, 2003).

The findings from the study carried out by UNCTAD (2011) show that loss carried forward relief may be targeted at investment in regions that are disadvantaged due to their remoteness from major urban centers. The study conducted by Hungerford (2012) in USA suggested that loss carried forward reliefs had no little association with investment, productivity, growth and saving In the study carried out by Oyetunde (2008), findings indicate that tax holidays are attractive to investment authorities in developing and transition economies with rudimentary corporate tax systems given their ease of administration. The study conducted by Porcano and Price, (2006) concluded that corporate taxes do not have a significant effect on investments.

The study by Morisset \& Pirnia (2000) shows that, "poor African countries have tended to rely on tax holidays and import duty exemption". Thus, this explains why tax holiday is one of the incentives for investment in Rwanda. Initial and annual allowances encourage investment in short -lived capital assets as supported by Oyetunde (2008). Reports by UNCTAD (2008) also support capital allowance as an important incentive for investments. Morisset \& Pirnia (2000) find that "industrialized countries have opted for investment allowances or accelerated depreciation" to encourage foreign direct investment. Bond \& Samuelson (1986) argued that investment allowance may be used by countries as signals of their "quality" as locations for foreign investment and investment incentives are presumed holding to encourage companies to invest more by increasing the rate of return from assets.

According to CITA (2004), there is no restriction on the amount of capital allowance that can be claimed from the profit of a company. Capital allowance cannot be claimed if the company incurs a loss. UNCTAD (2014) distinguished 6 main components of investments: New plants, plant expansions, mergers and acquisition, joint developing countries ventures, equity increases and other investments.

\section{Conclusion and Recommendations}

This section presents the conclusions and recommendations obtained from the findings of the study as well as the 
suggestions for future studies. Tax incentives have been adopted by governments as a policy tool for accelerating investment in specific economic sectors and shaping the investment environment of the country. Some of the efforts of the government to create a conducive environment for investment in Rwanda are such that Rwandan companies with a minimum of $40 \%$ foreign equity and within their first year of operation are exempt from payment of minimum tax. In addition, loans granted to Rwandan companies may be exempt from tax where the required conditions are met, tax holidays are granted to a company as a tax -free status for a certain period. The capital gain or loss is not due until the asset is finally disposed of and can be avoided if the asset is held until death or donated to charity. Based on the empirical evidences and results of the analysis, there is positive and statistically significant relationship between the tax incentives and investments. This implies foreign investors can maximize their investment by taking advantages of the available tax incentives allowed by the government to create an enabling investment environment

\subsection{Recommendations}

From the findings and conclusion, the following recommendations were established:

1. Governments should provide better company income tax exemptions but there are needs to conduct a cost benefit analysis for tax incentives available in the economy. The benefits accrued in terms of increase in level of investments should exceed revenue forgone by the government through tax exemptions. The government should ensure security and political stability and the infrastructure should be improved.

2. In order to promote SMEs, special tax incentive should be designed specifically for SMEs since most of the available tax incentives only favours large companies.

\section{References}

Action Aid International and tax justice network Africa. (2012). Tax competition in East Africa: A race to the bottom? Tax incentives and revenue losses in Rwanda. A 2006 report. International Monetary Fund (IMF). Washington, D.C IMF

Action Aid. (2013). Sweet Nothings: The Human Cost of a British Sugar Giant Avoiding Taxes in Southern Africa. Written and Researched by Lewis, M., Brooks R, Chisanga, P., Hearson, M., Jordan, C., Nshindano, K., Tharoor, A. \& Paul, W.

Anyanwu, J. C. (2011). Determinants of foreign direct investment inflows to Africa, 1980 -2007. African Development Bank Group, Working Paper, September, No. 136.

Barbour, P. (2005). An Assessment of South Africa's investment incentive regime with a focus on the manufacturing sector, ESAU Working Paper 14, Overseas Development Institute, London.

Barnet, K., \& Caren, G. (2004). Gender impact of government revenue collection: The case of taxation. Common Wealth Economic Paper Series Economic. Affairs of the London, United Kingdom. Common wealth Secretariat publishers. https://doi.org/10.14217/9781848590205-en

Basu, A., \& Srinivasan, k. (2012). Foreign direct investment in Africa: Some case studies. Working Paper WP/ 02/61.

Bond, E.W., \& Samuelson, L. (2016). Tax holidays as signals. American Economic Review, 76(2), 820-26.

Bond, S., \& Xing, J. (2013). Corporate taxation and capital accumulation. Centre for Business Taxation, Working Paper No. 1015.

Chukwumerije, T., \& Akinyomi, O. (2011). The impact of tax incentives on the performance of small-scale enterprises, Published Thesis, Redeemer's University, Ogun State, Nigeria.

Denisia, V. (2010) Foreign direct investment theories: An overview of the main FDI theories. European Journal of Interdisciplinary Studies, 2(2), 53-59.

Dunning, J. H. (2014). Location and the multinational enterprise: a neglected factor? In Location of international business activities. Palgrave Macmillan UK.

Dunning, J. H. (2008). Institutions and the OLI paradigm of the multinational enterprise. Asia Pacific Journal of Management, 25(3), 573-593. https://doi.org/10.1007/s10490-007-9074-z

Feldstein, M. (ed.) (2007). The effects of taxation on capital accumulation. Chicago: University of Chicago Press.

Fletcher, K. (2012). Tax incentives in Cambodia, Lao PDR, and Vietnam. Paper Prepared for the IMF Conference on Foreign Direct Investment. 
Glaeser, E.L. (2011). The economics of location-based tax. Incentives. Journal of Finance, 23(12), 201-231.

Hines Jr, J. R. (2015). Do tax havens flourish? In tax policy and the economy. Journal of finance, 19(20), 65-100.

Ifueko, O.O. (2012): "Tax incentives for foreign investors in Nigeria" at The Nigeria Investors Business Forum in Berne Switzerland.

Klemm, N., \& Parys, K. (2009, July). Empirical evidence on the effects of tax incentives. Journal of Accounting and Finance, 8(10), 18-39.

Kothari, C. (2014). Research methodology: Methods and Techniques (3rd ed.). New Delhi: New Age International.

Manson, R. (2016). A theory of tax discrimination, Jean Monnet Working Paper.

Morisset, J., \& Pirnia, N. (2010). How tax policy and incentives affect foreign direct investment: a review (Vol. 2509). World Bank Publications.

Mugenda, O. M., \& Mugenda, A. G. (2008). Research methods: Quantitative and qualitative. Nairobi Atlas Publications limited.

Neumayer, E., \& Laura. S. (2010). Do bilateral investment treaties increase foreign direct investment to developing countries? World Development, 33(10), 1567-1585. https://doi.org/10.1016/j.worlddev.2005.07.001

Orodho, A. J. (2013). Essentials of educational and social science research method. Nairobi: Masola Publishers.

Oyetunde, S. O. (2008). The role of tax incentives in a trio of Sub-Saharan African Economies: A comparative study of Nigerian, South African and Kenya Tax Laws. A PhD thesis for Centre for commercial Law studies, Queen Mary, University of London, England.

Smith, R. (2014). Exploring the usefulness of a conceptual framework as a research tool: A researcher's reflections. Issues in Educational Research, 14(19), 200-232.

Stapper, M. (2010). Tax regimes in emerging Africa corporate tax rates boost FDI in sub-Sahara Asia. Africa studies Centre working paper $88 / 2010$,

UNCTAD. (2010). Tax incentives and foreign direct investment, A global survey, United Nations. New York and Geneva: United Nations Publications.

UNCTAD. (2011). Foreign direct investment in LDCs: Lessons learned from the decade and the way forward. New York and Geneva: United Nations Publications.

UNCTAD. (2012). World investment report, 2012: Towards A new generation of investment policies. New York: United Nations Conference on Trade and Development.

UNCTAD. (2014). World investment report. New York: United Nations. United Nations Publications.

Wijeweera, A., Brian, D., \& Don C. (2007). Corporate tax-rates and foreign direct investment in the United States. Applied Economics, 39, 109-117. https://doi.org/10.1080/00036840500447872

Wheeler, D., \& Mody, A. (2012). International investment location decisions: The case for U.S. Firms. Journal of International Economics, 33(7), 57-76. 